\title{
STIMULASI GURU PADA PEMBELAJARAN BAHASA ANAK USIA DINI Endah Silawati $^{1}$
}

\begin{abstract}
Languange skill is one of important skills developed in early years of a child. It is more than a tool for communications; it is an avenue for creative expressionand tools that humans use to communicate or share thoughts, ideas and emotions (Loganet al., 1972).Right stimulation from adult, in this case: parents, other family members or teachers is needed to developed this skill. Unfortunately, when a child comes to school he is too often told to sit down and to be quite at a time when the right kind of talking is the key to succsesful learning (Logan et al., 1972).This paper is a part ofa studyabout the teachers' stimulations in language learning at Kindergarten held in Bandung in 2010. One of the aims of the study is to analize whether the language stimulations done by the teachers in Kindergarten are suitable with the concept of language stimulations based on theory proposed by Yawkey, et al. (1981).
\end{abstract}

\section{Keywords: Language skills, teachers' stimulations, early childhood}

\section{PENDAHULUAN}

\section{Latar Belakang Masalah}

Usia dini merupakan masa keemasan dimana seluruh aspek perkembangan anak berkembang dengan pesat. Diantara tahapan dan usia yang dilalui anak, masa usia dini adalah waktu yang paling potensial dalam proses pembelajaran. Hal ini dikarenakan perkembangan otak pada usia ini mencapai hampir $80 \%$. Salah satu aspek perkembangan yang berkembang pesat pada usia dini adalah perkembangan bahasa. Menurut Logan (1972) bahwa periode intensif dari perkembangan bahasa adalah 3 tahun pertama, ketika otak sedang berkembang dan menuju proses pematangan.

Bahasa merupakan aspek yang sangat penting bagi kehidupan anak kedepannya. Apalagi di era komunikasi global saat ini yang tentu saja menggunakan bahasa sebagai media komunikasi. Segala sumber ilmu dan informasi bermediakan bahasa. Ketika kemampuan bahasa anak terhambat, maka dikhawatirkan akses anak terhadap ilmu dan informasi akan terhambat. Sedangkan anak adalah cikal bakal SDM (Sumber Daya Manusia) di masa yang akan datang. SDM masa depan tidak akan berkualitas baik jika aksesnya terhadap ilmu dan informasi terhambat karena kemampuan dasarnya, yaitu kemampuan bahasa terhambat.

Karena itu pengembangan kemampuan bahasa sedini mungkin. Anak yang bermasalah dengan kemampuan bahasa ekspresif, akan mengalami kesulitan dalam kegiatan pembelajarannya dan merasa frustasi karena dia tidak bisa mengemukakan ide dengan baik. Jika tidak diatasi sejak kecil, hal tersebut akan terus berlanjut sampai dewasa dan kemampuan akademiknya akan mengalami masalah.

Dalam mengembangkan kemampuan berbahasa, anak memerlukan orang dewasa yang memberi stimulasi, baik di rumah, sekolah maupun lingkungan sekitarnya. Orang dewasa yang memiliki peran paling utama dan pertama adalah orang tua, terutama ibu. Orang tua memiliki peran yang sangat penting dalam setiap tahap perkembangan bahasa anak. Ikatan emosional yang mendalam antara ibu dan anak, akan membentuk pola respon tertentu bagi anak terhadap stimulus dari luar, atau dengan kata lain apa yang dilakukan seseorang pada dasarnya merupakan refleksi dari apa yang mereka ketahui dan alami pada masa kanakkanak dari orang tuanya terutama ibunya.

Selain keluarga, lingkungan di sekitar anak pun turut mempengaruhi perkembangan bahasa anak. Jika anak bersekolah, maka lingkungan selanjutnya yang mempengaruhi

\footnotetext{
${ }^{1}$ Dosen PGPAUD UPI Kampus Cibiru
} 
perkembangan bahasa adalah sekolah. Sebuah penelitian tentang pengaruh pembelajaran anak di sekolah, pernah dilakukan oleh Lippitt dan White (Logan 1972). Hasil penelitian tersebut menemukan jika anak belajar dalam suasana pembelajaran yang demokratis dimana dia diberi kesempatan untuk berbicara, dimintai pendapat dan bisa memutuskan sesuatu, maka perkembangan bahasanya akan optimal. Sedangkan jika anak belajar dalam suasana yang penuh otoritas guru, maka dia akan tumbuh menjadi apatis dan kemampuan komunikasinya terhambat.

Ketika anak memasuki usia TK, perkembangan bahasanya belum sempurna. Mereka masih memiliki keterbatasan dalam pengalaman dan pemahaman tentang dunia di sekitarnya. Mereka membutuhkan suatu kesempatan untuk bisa berbicara, berdiskusi, menyusun hipotesis dan sintesis. Karena itu, guru sebagai fasilitator sebaiknya menyusun pembelajaran yang memberikan stimulasi perkembangan bahasa anak seperti diskusi, cerita yang kreatif, film, dsb. Hal tersebut akan membantu menciptakan makna dari pengalaman mereka sendiri dalam dunia nyata ke dalam variasi simbol linguistik yang lebih luas.

Sayangnya, mayoritas pembelajaran bahasa di TK masih menggunakan cara konvensional, bersifat akademis dan jauh dari suasana bermain serta pendekatan Whole Language yang seharusnya menjadi dasar pembelajaran bahasa. Selain itu, pengembangan bahasa di TK selama ini lebih menekankan pada kemampuan membaca dan hanya kemampuan teknis menulis, bukan bagaimana cara mengekspresikan ide lewat tulisan meski masih sederhana. Padahal kemampuan bahasa ekspresif tidak kalah pentingnya untuk dikembangkan karena berhubungan dengan kemampuan mengkomunikasikan ide baik secara lisan dan tulisan yang sangat penting dalam proses pembelajaran anak selanjutnya. Selain itu, hal tersebut sangat esensial bagi manusia karena berhubungan dengan realisasi diri sendiri sesuai dengan yang dikemukakan (Logan, 1972).

Secara akademik, TK adalah suatu bidang kajian yang mempelajari cara-cara efektif dalam membantu anak usia TK agar tumbuh dan berkembang sesuai dengan tingkat perkembangannya (Dunn \& Kontos. 1997; Katz, 1987; Bredecamp, 1987 dalam Supriadi, 2002). Dari tujuan di atas tampak bahwa pendidikan bagi anak usia dini khususnya di TK atau pra sekolah, tidak saja membantu mempersiapkan anak untuk memasuki pendidikan di sekolah dasar, tapi juga membantu meletakkan dasar perkembangan sikap, pengetahuan, keterampilan dan daya cipta yang diperlukan anak dalam menyesuaikan diridengan lingkungannya dan untuk pertumbuhan serta perkembangan selanjutnya. Ketika pembelajaran yang didapatkan anak di TK tidak sesuai dengan prinsip perkembangan dan pendidikan anak, maka dipastikan, anak akan mengalami hambatan pada jenjang pendidikan selanjutnya. Termasuk dalam hal kemampuan berbahasa.

Karena itu, dalam rangka meningkatkan kemampuan berbahasa dan mutu pengajarannya di TK, diperlukan informasi yang berbasis penelitian tentang stimulasi yang tepat dalam pembelajaran bahasa. Selain itu, informasi tersebut akan sangat bermanfaat pula bagi pengembangan pembelajaran bahasa di SD sebagai jenjang pendidikan selanjutnya. Artikel ini ditulis berdasarkan penelitian yang dilakukan pada tahun 2010 di tiga TKN Pembina Kota Bandung yang diasumsikan sebagai TK unggulan dan berfungsi membina TK yang lain.

\section{Identifikasi Masalah}

Dari latar belakang masalah yang telah dipaparkan, bisa disimpulkan bahwa kemampuan bahasamerupakan hal yang sangat penting bagi pemerolehan kemampuan bahasa selanjutnya. Kemampuan berbahasa pun adalah kunci dalam proses pembelajaran dan sosialisasi anak. Kemampuanbahasaanakmencakupkemampuanbahasareseptif dan kemampuanbahasaekspresif yangsalingmempengaruhisatu sama lain. Ketikakemampuanbahasa lisan anakterhambatmakakemampuanbahasatulis dan membacanya pun akanterhambat. 
Selamainipengembanganbahasa di TK lebihmenekankan pada kemampuanmembaca, padahalkemampuanbahasaekspresifbaik lisan maupuntulisantidakkalahpentingnyauntukdikembangkankarenaberhubungandengankemampu anmengkomunikasikanide. Kemampuantersebutsangatpentingdalamproses pembelajaran anakselanjutnya. Anak yang bermasalahdengankemampuanbahasaekspresif, akankesulitandengankegiatanpembelajarannya dan merasafrustasikarenadiatidak bisa mengemukakan idedenganbaik. Jikatidakdiatasisejakkecil, haltersebutakanterusberlanjutsampaidewasa dan kemampuanakademiknyaakanmengalamimasalah (Morales, 2004)

Kekurangfahamanguruakanprinsip pembelajaran bahasauntukanak usia dini menjadi faktor yang menyebabkan kurang idealnya stimulasi kemampuan berbahasa. Karenaitu, diperlukaninformasi yang akuratmengenaistimulasi yang tepatdalam pembelajaran bahasa, khususnyakemampuanbahasaekspresif.

\section{Rumusan Masalah}

Berdasarkan anggapan bahwa kemampuan bahasa pada tahap pra sekolah sangat penting bagi perkembangan bahasa selanjutnya (Logan dkk, 1972) dan stimulasi pembelajaran yang diberikan guru merupakan faktor yang sangat penting dalam pengembangannya, maka penelitian ini difokuskan untuk mengetahui apakah stimulasi guru pada pembelajaran berbahasa sudah ideal atau tidak.

\section{Ruang Lingkup Penelitian}

Kemampuan Bahasa merupakan bidang yang sangat luas untuk dikaji. Karena itu, penulis membatasi ruang lingkup penelitian tentangstimulasi kemampuan bahasa di TK Pembina se-Kota Bandung yang diasumsikan sebagai TK unggulan.

Stimulasiguru pada pembelajaran bahasa yang dikaji pada penelitianinimenyangkutbeberapa aspek sesuai dengan yang dikemukakan Yawkey dkk (1981), yaitu: (1) pengembangankefasihan berbahasa, (2) pengembangankemampuansintaksis, (3) pengembangan penguasaan kosa kata, (4) pengembanganpengintegrasiankemampuanbahasadalamkehidupansehari-hari,

(5)pengembangankemampuanmengekspresikandirisendiri.

\section{Tujuan Penelitian}

Berdasarkan latar belakang masalah di atas, tujuan penelitian ini adalah menyajikan analisis deskriptif mengenaistimulasi yang dilakukan guru untuk mengembangkan kemampuan bahasa anak usia dini.

\section{KAJIAN PUSTAKA}

\section{Pemerolehan dan Perkembangan Bahasa Anak}

Seperti halnya aspek perkembangan lain, bahasa pun tidak serta merta diperoleh seorang individu secara langsung, tapi bertahap seiring dengan aspek perkembangan yang lainnya. Proses anak mulai mengenal komunikasi dengan lingkungannya secara verbal disebut dengan pemerolehan bahasa anak. Pemerolehan bahasa pertama anak terjadi bila anak yang sejak semula tanpa bahasa kini telah memperoleh satu kemampuan bahasa. Pemerolehan ini lebih mengarah pada fungsi komunikasi daripada bentuk bahasanya dan mempunyai ciri kesinambungan serta memiliki suatu rangkaian kesatuan, yang bergerak dari ucapan satu kata sederhana menuju gabungan kata yang lebih rumit.

Perkembangan bahasa anak berlangsung melalui suatu proses dan tahapan tertentu. Meskipun perkembangan bahasa setiap anak memiliki keunikan tersendiri, tapi pada umumnya proses dan tahapan tersebut dilalui oleh semua anak. Terkecuali bila ada faktor penghambat perkembangan seperti sakit atau faktor bawaan. Proses perkembangan bahasa terjadi dalam dua tipe, yaitu tipe egocentric speech, dan tipe socialized speech (Yusuf, 2004). Pada tipe egocentric speech, anak berbicara kepada dirinya sendiri (monolog) untuk 
mengungkapkan keinginan diri tanpa memperhatikan keinginan dan komunikasi dua arah. Biasanya ini terjadi pada anak berusia 2-3 tahun. Berbicara monolog berfungsi untuk mengembangkan kemampuan berfikir anak.

Tipe yang kedua yaitu Socialized Speech, terjadi ketika anak berinteraksi secara langsung dengan teman atau lingkungannya. Perkembangan ini dibagi ke dalam lima bentuk: (a) adapted in formation, di sini terjadi saling tukar gagasan atau adanya tujuan bersama yang dicari, (b) critism, yang menyangkut penilaian anak terhadap ucapan atau tingkah laku orang lain (c) command (perintah), request (permintaan) dan threat (ancaman) (d) questions (pertanyaan) dan (e) answers (jawaban). Tipe ini mengembangkan kemampuan penyesuaian sosial (social adjustment).

Meskipun anak sudah mulai berinteraksi dengan lingkungannya, konstruksikonstruksi bahasa yang sangat rumit belum bisa mereka kuasai. Bentuk-bentuk bahasa formal, seperti bahasa pendidikan, bahasa pidato, bahasa diskusi, bahasa buku, dan sejenisnya masih di luar jangkauan penguasaan anak. Tapi akuisisi bahasa mereka mulai semakin luas dan semakin memahami fungsi bahasa sebagai alat komunikasi sesuai dengan perkembangan sosial-budaya. Bahasa akademis dan bahasa tulis anak-anak peroleh pada saat mereka berada di masa pendidikan formal. Kemampuan bahasa anak tersebut akan terus berkembang seiring dengan perkembangan budaya tempatnya dibesarkan. Semakin maju suatu bangsa, semakin rumit bentuk komunikasi yang terjadi sesuai dengan kerumitan perkembangan budaya yang berkembang dalam masyarakatnya, maka akan semakin berkembang pula kemampuan seseorang.

Banyak ahli bahasa yang membagi tahapan perkembangan bahasa anak. Diantaranya Logan dan Brown. Logan dkk (1972) membagi tahap perkembangan bahasa anak menjadi tujuh tahap. Tahapan tersebut adalah sebagai berikut:

1) Tahap Random

Tahap random dikenal sebagai fase pra linguistik. Pada tahap ini anak bergumam dan mulai berintekasi dengan bunyi, tapi bukan sebagai bahasa sampai anak mampu mengkomunikasikan kebutuhannya dan mendapatkan respon yang dia harapkan. Anak menangis ketika dia ditinggalkan sendiri, lapar atau ngompol. Kemudian anak mulai menyukai menyusun bunyi selain menangis. Pada usia enam bulan, anak memasuki tahap babling (bergumam). Anak mulai menggunakan berbagai bunyi vokal dan konsonan yang akan menjadi dasar pengembangan bahasa selanjutnya. Selama tahap ini, Anak mengutarakan berbagai jenis suara yang kebanyakan hanya para ahli bahasa yang bisa mengidentifikasinya. Bayi harus didukung dalam fase pra linguistik perkembangan bahasa ini. Dia sedang membangun pola menuju kesempurnaan kemampuan berbicara. Semua bayi memiliki peluang yang sama, tapi bayi yang memiliki kesempatan lebih baik untuk mengembangkan kemampuan bahasanya dari pada bayi yang sering di protes atau menangis akan memiliki kemampuan bahasa yang baik.

2) Tahap Jargon

Tahap ini terjadi pada usia sekitar 6 bulan. Pada usia ini, seorang bayi akan semakin terlibat dengan berbagai suara yang dia dengar dan mulai menyukai membuat ujaran. Bayi akan mengulang-ngulang suara yang menarik bagi dia dan mencontoh pola melodi orang yang berbicara dengannya. Di tahap ini, bayi akan memiliki kemampuan memilih suara tertentu.

3) Tahap Echalalia

Pada tahap ini anak mengimitasi suara yang benar-benar dia dengar. Dia secara langsung berusaha mengulangi suara yang diutarakan ibunya dan orang dewasa lain. Ini merupakan awal dari kemampuan bahasa anak. Suara yang telah dia utarakan tapi tidak sering didengarkan oleh orang dewasa disekelilingnya akan hilang. Dia hanya menguasai suara yang membawa respon dari orang disekitarnya. 


\section{4) Tahap Ekspansi}

Tahap ini dilalui anak pada usia dua tahun, ketika dia sudah bisa berbicara. Anak akan belajar nama orang yang sering berinteraksi dengannya dan objek serta peristiwa yang paling menarik baginya. Jargon yang anak gunakan untuk mengimitasi suara orang dewasa dalam usahanya untuk berbicara dengan lancar semakin menuju kesempurnaan. Selain itu, anak semakin lebih tertarik berkomunikasi dengan orang dewasa. Artinya dia harus menggunakan simbol lisan yang bermakna bagi orang dewasa. Pada tahap awal dua tahun ini, anak akan banyak menggunakan kata benda terutama nama benda- benda yang sering dia lihat, sentuh dan dengar. Enam puluh lima persen kata yang dia gunakan ketika usia tiga belas sampai dua puluh tujuh bulan adalah kata benda. Sedangkan ketika menginjak tiga sampai empat tahun, hanya dua puluh persen anak menggunakan kata benda. Pada usia tiga tahun anak mulai bisa berbicara bahasa dalam kalimat lengkap. Ketika usia empat tahun anak mulai menggunakan kalimat perintah dan berimbuhan.

5) Tahap Kesadaran Struktur

Ketika anak mulai membangun kemampuan persepsi dan observasi, dia menjadi tertarik bermain kata-kata dan menyusun bahasanya sendiri. Anak menggunakan kelompok kata, frase dan kalimat yang dia dengar dari orang lain. Anak menyusun peraturannya sendiri tentang bagaimana menyusun kata dan memperoleh lebih banyak makna dari kata dan frase. Anak suka menciptakan ujaran yang dia coba utarakan pada teman dan keluarganya. Karena anak pada tahap ini cenderung berfikir lebih cepat dari pada bicaranya, terkadang mereka memerlukan waktu mencari kata. Anak-anak butuh waktu untuk mengekspresikan ide mereka, terkadang mereka berbicara dengan suara pelan atau jeda sampai mereka menemukan kata yang tepat. Jika mereka di tekan untuk cepat dalam bicara, mereka bisa tumbuh menjadi anak yang gagap.

6) Tahap Respon Otomatis

Seiring dengan anak mencapai tahapan otomatis dari perkembangan bahasa, kemampuan berfikirnya sangat meningkat. Pada gilirannya, membuat dia memiliki kemampuan bahasa. Anak cenderung bergerak dari tujuan individual dalam berkomunikasi menuju pola komunikasi yang dia temukan di lingkungannya. Apapun dialeknya, ketika anak telah mencapai tahap mengontrol secara otomatis, hal itu membuat dia mampu mengkomunikasikan ide-idenya pada orang di sekelilingnya dan memberi respon pada anak yang seusia dengannya. Rata-rata anak telah mencapai tahap otomatis ketika usia TK. Dia telah menguasai tata bahasa dasar dan menggunakannya di rumah, lingkungan dan masyarakat sekitar.

7) Tahap Kreatif

Kecenderungan anak bermain kata, menciptakan model komunikasinya sendiri terjadi pada usia SD. Ketika mereka mampu untuk memperluas cakupan dalam menggunakan bahasa di atas batasan seharusnnya, maka mereka berada dalam tahap komunikasi yang kreatif. Pada saat tersebut, mereka meningkatkan kemampuan dalam berfikir kreatif dan kritis, mereka mampu membuat metafora dan abstrak, mereka menyukai mengekspresikan diri sendiri baik lewat bahasa lisan atau tulisan.

Dari pembagian tahapan menurut Logan dkk (1972), anak TK masuk pada tahapan ekspansi, kesadaran struktur dan respon otomatis. Bisa disimpulkan bahwa anak TK dengan rentang usia 4 s.d. 6 tahun idealnya sudah bisa menyusun kalimat-kalimat kompleks dan gabungan mesti masih terbatas serta sudah mengetahui struktur sederhana kalimat. Hal ini sesuai dengan pendapat para ahli psikolinguis, yang menyatakan bahwa sampai dengan umur empat tahun, anak-anak sudah menguasai kosa kata, gramatika, makna semantis/paragmatis, dan wacana yang berhubungan dengan pengalaman mereka sehari-hari. Mereka mulai mahir mengkomunikasikan ide-idenya dan memberi respon pada orang yang berbicara padanya. Fase egocentric speech mulai ditinggalkan dan anak mulai memasuki sosialize speech. 
Dari semua tahapan yang akan dilalui anak dalam perkembangan bahasanya, terdapat tugas-tugas perkembangan bahasa yang harus dikuasai anak. Menurut Yusuf (2004), dalam berbahasa, anak dituntut untuk menuntaskan atau menguasai empat tugas pokok yang satu sama lain saling berkaitan. Apabila anak berhasil menuntaskan tugas yang satu, maka ia juga dapat menuntaskan tugas yang lainnya. Tugas perkembangan bahasa anak tersebut adalah sebagai berikut:

(a) Pemahaman, yaitu kemampuan memahami makna ucapan orang lain. Bayi memahami bahasa orang lain, bukan memahami kata-kata yang diucapkannya, tetapi dengan memahami gerakan atau gesture-nya (bahasa tubuhnya)

(b) Pengembangan perbendaharaan kata. Perbendaharaan kata-kata anak berkembang dimulai secara lambat pada usia dua tahun pertama, kemudian mengalami tempo yang cepat pada usia pra sekolah dan terus meningkat setelah anak masuk sekolah.

(c) Penyusunan kata-kata menjadi kalimat. Kemampuan menyusun kata-kata menjadi kalimat pada umumnya berkembang sebelum usia dua tahun. Bentuk kalimat pertama adalah kalimat tunggal (kalimat satu kata) dengan disertai gesture untuk melengkapi cara berfikirnya. Contohnya, anak menyebut "bola” sambil menunjuk bola itu dengan jarinya. Kalimat tunggal itu berarti "tolong ambilkan bola untuk saya”. Seiring dengan meningkatnya usia anak dan keluasan pergaulannya, tipe kalimat yang diucapkannya pun semakin panjang dan kompleks. Menurut Davis, Garrison \& Mccarthy (E. Hurlock, 1956) anak yang cerdas, anak wanita dan anak yang berasal dari keluarga berada, bentuk kalimat yang diucapkanya itu lebih panjang dan kompleks dibandingkan dengan anak yang kurang cerdas, anak pria dan anak yang berasal dari keluarga miskin.

(d) Ucapan. Kemampuan mengucapkan kata-kata merupakan hasil belajar melalui imitasi (peniruan ) terhadap suara-suara yang didengar anak dari orang lain (terutama orangtuanya). Pada usia bayi, antara 11-18 bulan, pada umumnya mereka belum dapat berbicara atau mengucapkan kata-kata secara jelas, sehingga sering tidak dimengerti maksudnya. Kejelasan ucapan itu baru tercapai pada usia sekitar tiga tahun. Hasil studi tentang suara dan kombinasi suara menunjukan bahwa anak mengalami kemudahan dan kesulitan dalam huruf-huruf tertentu. Huruf yang mudah diucapkan yaitu huruf hidup (vokal): i, a, e dan u dan huruf mati (konsonan): t, p, b, $\mathrm{m}$, dan n, sedangkan yang sulit diucapkan adalah huruf mati tunggal: $\mathrm{z}, \mathrm{w}, \mathrm{s}$ dan $\mathrm{g}$, dan huruf mati rangkap (diftong); st, str, sk dan dr. ].

Tugas-tugas perkembangan bahasa tersebut bisa tercapai dengan optimal bila sejak awal, anak diberi stimulasi untuk mencapai setiap kemampuan tersebut. Stimulasi tersebut terutama dilakukan di rumah sebagai lingkungan sosial pertama anak.

\section{Konsep Pembelajaran Bahasa di Taman Kanak-Kanak}

Ketika anak memasuki TK, perkembangan bahasanya belum sempurna. Pengalaman dan pemahaman mereka tentang dunia disekitarnya masih terbatas. Anak membutuhkan suatu kesempatan untuk bisa berbicara, berdiskusi, menyusun hipotesis dan sintesis. Karena itu pembelajaran di TK perlu dikembangkan ke arah pemberian stimulasi perkembangan bahasa anak seperti diskusi, cerita yang kreatif, film,dsb. Hal tersebut akan membantu menciptakan makna dari pengalaman mereka sendiri dalam dunia nyata ke dalam variasi simbol linguistik yang lebih luas.

Anak-anak mempelajari bahasa dengan cara menggunakannya. Mereka membangun kemampuan berbahasa melalui interaksi secara verbal dan non verbal dengan orang dewasa dalam lingkungan sosial mereka. Orang dewasa tersebut bisa anggota keluarga, guru atau yang lain. Interaksi tersebut lebih banyak mendengar. Karena itu lingkungan tempat anak tumbuh harus memberi pengalaman kebahasaa yang kaya baik dari segi variasi maupun 
frekuensi, sebab pembelajaran bahasa itu tidak terjadi begitu saja, tapi melalui suatu proses. Dalam hal ini, guru merupakan katalis yang menciptakan stimulasi perkembangan dalam setiap fase di lingkungan yang kaya akan kegiatan kebahasaan.

Pembelajaran bahasa pada usia dini memiliki karakteristik tersendiri. Menurut Yawkey dkk (1981) hal pertama yang harus diperhatikan dalam pembelajaran bahasa adalah tahapan perkembangan anak secara keseluruhan, karena pada usia ini terjadi perkembangan pesat dalam berbagai aspek perkembangan anak yang akan sangat menentukan taraf optimalisasi perkembangan berikutnya. Dalam merumuskan pembelajaran bahasa, perlu dijabarkan terlebih dahulu mengenai tujuan dan fungsi pembelajaran pada anak usia itu sendiri.

Ada beberapa aliran yang berpengaruh di dunia ilmudalam mengartikan belajar. Belajar menurut teori behaviorisme yang agak radikal adalah perubahan perilaku yang terjadi melalui proses stimulus dan respon yang bersifat mekanis. Oleh karena itu, lingkungan yang sistematis, teratur dan terencana dapat memberikan pengaruh (stimulus) yang baik sehingga manusia bereaksi ierhadap stimulus tersebut dan memberikan respon yang sesuai (Semiawan, 2002 :3).

Johan H. Pestalozzi (Santoso, 2002 : 11) mengemukakan metodenya yang merupakan perpaduan yang serasi antara natural dan pendidikan yang praktis, yaitu membimbing anak dengan perlahan dan dengan usaha anak sendiri. Pestalozzi yakin bahwa segala bentuk pendidikan adalah berdasarkan pengaruh dan panca indera dan melalui pengalamannya potensi-potensi yang dimilikinya dapat dikembangkan. Cara belajar yang terbaik adalah melalui berbagai pengalaman dengan menghitung, mengukur, merasakan, danmenyentuhnya.

Beberapa pandangan para ahli seperti Pestalozzi, Froebel, Montessori (Santoso, 2002), Piaget (Hoom, 1993), Vigotsky (Musthafa, 2000) mengemukakan bahwa belajar yang sesuai dengan taraf perkembangan anak akan membantu anak dalam mengembangkan dirinya dalam aspek kognitif, linguistik, dan sosio emosionalnya.Berbagai teori tentang belajar terkait dengan penekanan terhadap pengaruh lingkungan dan pengaruh potensi yang dibawa sejak lahir. Potensi itubiasanya merupakan kemungkinan kemampuan umum.

Seseorang secara genetis telah lahir dengan suatu organ yang disebut kernampuan umum (inteligensi) yang bersumber dari otaknya. Apabila struktur otak telah ditentukan secara biologis, berfungsinya otak tersebut sangat dipengaruhi oleh interaksi dengan lingkungannya (Semiawan, 2002). Jadi apabila lingkungannya berpengaruh positif bagi dirinya, kemungkinan besar potensi tersebut berkembang mencapai realisasi optimal.

Pendapat lain mengatakan bahwa anak-anak belajar melalui kegiatan yang dilakukannya. Pandangan Piaget, Montessori (Santoso, 2000), Erikson dan ahli-ahli perkembangan anak serta para peneliti lainnya (Hainstock, 2002 ; Katz, 1991; Hoorn, 1993; dalam Musthafa, 2000) telah memperlihatkan bahwa belajar adalah suatu proses yang komplek sebagai hasil dari interaksi pemikiran anak-anak sendiri dengan pengalaman mereka dengan dunia luarnya.Teori perkembangan yang diajukan Piaget, telah memberikan sumbangan besar bagi upaya pendidikan dan nembelajaran. Sedikitnya, tahapan (perkembangan) yang dikemukakannya telah memberikan gambaran umum tentang kecenderungan anak-anak usia dini (Musthafa, 2002 :2).

Kematangan adalah satu kontributor penting dalam belajar. sebab menyediakan kerangka kerja dari proses belajar anak Sebagai contoh, ketika anak tumbuh secara fisik, mereka menjadi lebih berkemampuan untuk memanipulasi dan menjelajahi lingkungan mereka. Juga ketika mereka matang. Mereka menjadi lebih dapat mengerti titik pandang orang lain.Pengetahuan bukan sesuatu yang diberikan kepada anak sebagai pemikiran mereka adalah ruang kosong yang harus diisi. Anak-anak mendapatkan pengetahuan tentang dunia fisik dan sosial dimana mereka mengalami dalam interaksinya dengan objek dan 
manusia. Anak-anak tidak membutuhkan penekanan untuk belajar,mereka termotivasi dengan sendirinya melalui keinginannya untuk mengerti dunianya (Bredekamp, 1987 : 51).

Berikut inidisajikan sintesis prinsip-prinsip pembelajaran dan berbagai sumber untuk dipertimbangkan dalam mendesain intervensi pembelajaran anak usia dini di taman kanak-kanak (Musthafa, 2002:4).

1) Berangkat dari yang dibawa anak-anak.

Semua upaya pembelajaran harus bermula dan berakhir pada kebaikan perkembangan peserta didik. Selain itu, suatu pemahaman baru dapat dibangun kalau peserta didik mau dan mampu menghubungkan sesuatu yang baru ditemuinya itu dengan apa yang telah terlebih dulu diketahui dan dipahaminya. Dengan demikian. hubungan dapat dibangun antara pemahaman yang telah ada dengan pemahaman yang baru.

2) Aktivitasbelajar harus menantang pemahaman anak dari waktu ke waktu.

Proses belajar dapat terjadi dalam dua arah dari umum ke khusus dan yang spesifik ke yang general. Akan tetapi,suatu pemahaman barutersusun atas pengetahuan kasus perkasus melalui proses peninjauan ulang.Oleh karena itu, untuk memastikan terjadinya pengembangan dan pendalaman, pemahaman dalam diri peserta didik, aktivitas pembelajaran yang dirancang guru haruslah diatur sedemikian rupa sehingga dari waktu ke waktu input yang diberikan membuat pembelajar tergerak untuk meninjau kembali pemahamannya dan dengan demikian pembelajar dapat mengkonsolidasi atau mengembangkan dan mendalamkan pemahamannya sesuai bukti-bukti baru yang ditemuinya.

3) Guru menyodorkan persoalan-persoalan yang relevansinya tengah dirasakan pembelajar.

Belajar adalah proses pengolahan selektif yang kebermaknaannya ditentukan oleh relevansi yang dilihat dan dirasakan pembelajaran pada suatu tertentu. Oleh karena itu, untuk memastikan bahwa proses belajar terjadi sekerap mungkin dalam diri peserta didik,guru harus waspada untuk dapat 'menangkap' momentum kebutuhan belajar peserta didik.

4) Guru membangun unit-unit pembelajaran seputar konsep-konsep pokok dan tema-tema besar.

Tidak seperti orang dewasa yang dapat dengan mudah belajar melalui abstraksi atomistik, anak-anak usia taman kanak-kanak belajar secara holistik dan terintegrasi. Mengingat kecenderungan ini,dalam membantu membelajarkan anak usia taman kanak, guru seyogianya mengupayakan agar yang disampaikan kepada peserta didik itu berbentuk konsep-konsep esensial dan tema-tema besar yang mudah dikontekstualisasikan dan tidak dalam bentuk serpihan fakta yang terpisah-pisah.

Program pendidikan prasekolah merupakan suatu upaya memfasilitasi perkembangan anak yang sifatnya komprehensif dan menyeluruh serta memberikan pengaruh yang sangat fundamental bagi optimalisasi perkembangan anak selanjutnya. Fungsi umum pendidikan pra sekolah adalah memfasilitasi pertumbuhan dan perkembangan anak secara optimal dan menyeluruh sesuai dengan norma-norma dan nilai-nilai kehidupan yang dianut. Fungsi tersebut adalah: 1) fungsi pengembangan potensi, 2) fungsi penanaman dasar-dasar aqidah dan keimanan, 3) fungsi pembentukan dan pembiasaan prilaku-prilaku yang diharapkan, 4) fungsi pengembangan pengetahuan dan keterampilan dasar yang diperlukan, dan 5) fungsi pengembangan motivasi dan sikap belajar yang positif

Dari jabaran mengenai fungsi pendidikan pra sekolah di atas, pembelajaran bahasa masuk pada kategori pengembangan pengetahuan dan keterampilan dasar yang diperlukan. Tapi tentu saja pengembangan pembelajarannya tidak boleh terlepas dari fungsi-fungsi yang 
lain, sesuai dengan pendapat Solehudin (2004) bahwa pendekatan pembelajaran pra sekolah idealnya terpadu dan menyeluruh.

Anak mendapatkan kesempatan yang seluas-luasnya untuk mengembangkan dan memperdayakan potensi-potensi yang dimilikinya sesuai dengan taraf pengembangannya. Dengan kata lain pendidik menyediakan pengalaman-pengalman belajar kepada anak dalam arti luas sehingga dapat merangsang perkembangan kemampuan-kemampuan potensial tersebut secara optimal. Termasuk dalam pemberian pengalaman kebahasaan. Guru harus memotivasi siswa untuk aktif menggunakan berbagai fitur bahasa. Karena untuk aktif bermasyarakat, anak harus memiliki kemampuan untuk berkomunikasi secara efektif dalam berbagai pola dan situasi komunikasi. Karena mereka tidak bisa belajar sendiri, tapi harus ada stimulasi dari orang dewasa di sekitarnya, sesuai dengan pernyataan Logan (1972) bahwa anak harus diberi stimulasi dan dibantu untuk bisa berkomunikasi. Tanpa bantuan tersebut, tanpa keahlian dalam komunikasi verbal, anak-anak pada saat ini tidak akan memiliki kesiapan menghadapi tantangan masa depan. Peran berbagai media komunikasi dunia dalam masyarakat modern mencatat perlunya pengembangan kemampuan komunikasi dan bahasa di sekolah.

\section{Stimulasi Guru pada Pembelajaran Bahasa Anak Usia Dini}

Menurut Musfirah (2009) stimulasi mengandung arti membangkitkan sesuatu kekuatan atau kemampuan yang sebenarnya sudah ada dalam diri seorang anak yang tidak bersifat memaksa dan tidak mengandung target kemampuan tertentu.Makna stimulasi tersebut dalam pembelajaran bahasa berarti merangsang anak untuk mengunakan bahasa dalam berkomunikasi untuk mengungkapkan ide dan perasaannya.

Sesuai dengan tujuan dan fungsi pendidikan prasekolah yang bersifat komprehensif dan menyeluruh, orientasi pembelajaran bagi anak usia prasekolah bersifat luas. Artinya, kegiatan pembelajaran itu tidak hanya diarahkan untuk membuat anak menguasai sejumlah konsep pengetahuan dan atau keterampilan, melainkan juga diarahkan untuk mengembangkan sikap dan minat belajar serta berbagai potensi dan kemampuan dasar anak.

Oleh sebab itu, stimulasi pada pembelajaran bahasa untuk anak usia dini diarahkan melalui bermain, karena bermain adalah sumber perkembangan dan membentuk zona perkembangan proksimal (ZPD) (Vygotski, 1967 dalam Musfirah, 2009).

Strategi-strategi tersebut akan efektif ketika didukung oleh guru yang memiliki kemampuan untuk mengelola pembelajaran sedemikian rupa, sehingga anak mendapatkan stimulasi yang tepat untuk kemampuan bahasanya. Menurut Yawkey (1981) setidaknya ada beberapa stimulasi yang bisa dilakukan guru, diantaranya sebagai berikut.

(1) Pengembangan kefasihan berbahasa

- Mengadakan situasi pembicaraan yang bisa dimengerti dan diikuti anak.

- Memberikan kebebasan pada anak untuk memberi respon berdasarkan pengalaman dia sendiri dan menggunakan bahasa dia sendiri.

- Mendorong anak untuk berbicara, anak lain baik sendiri maupun dalam kelompok sebagaimana dengan guru, sehingga lawan bicara anak mayoritas adalah teman sebayanya dari pada guru.

(2) Pengembangan kemampuan sintaksis

- Menyusun permainan atau situasi dimana anak secara alamiah menggunakan fiturfitur bahasa.

- Menyediakan berbagai model fitur (guru, orang dewasa lain dan teman sebayanya, rekaman)

- Mengevaluasi secara hati-hati kelanjutan perkembangan.

- Mengevaluasi dialek anak yang berbeda dengan standar bahasa Indonesia, sehingga bahasa yang digunakan guru tidak jauh berbeda dengan bahasa yang digunakan anak.

(3) Pengembangan penguasaan kosa kata

- Menyusun pengalaman pembelajaran di bidang sains, pengetahuan sosial, 
matematika, kesehatan dan keahlian kecakapan hidup yang memasukan pembelajaran kosa kata baru bagi anak.

- Memastikan kosa kata baru yang dipelajari tidak terlalu banyak sehingga mudah diasimilasikan oleh anak.

- Menyusun pengalaman pembelajaran lanjutan yang membuat anak menggunakan kosa kata baru secara alamiahdan membantu pengembangan konsep makna dari kata baru tersebut.

- Mengintegrasikan penggunaan bahasa dalam kehidupan sehari-hari baik di dalam maupun di luar sekolah.

(4) Pengembangan pengintegrasian kemampuan bahasa dalam kehidupan sehari hari

- Menyusun pengalaman pembelajaran yang membuat anak mendeskripsikan kehidupan di luar sekolah (kegiatan, tempat, dan benda-benda yang berhubungan dengan kehidupan pribadi anak)

- Mendorong anak untuk berbagi dengan anak lain dan orang dewasa tentang reaksi dan perasaannya mengenai apa yang terjadi di sekolah dan diluar sekolah.

- Menyertakan anggota dan kegiatan masyarakat dalam pengalaman pembelajaran di kelas.

(5)Pengembangan kemampuan mengekspresikan diri sendiri

- Menerima dan menghargaiperasaan dan responanak.

- Menyusun situasi yang mendorong respon kreatif dan penggunaan imajinasi.

- Menyediakan waktu dan tempat untuk anak berfikir dan berimajinasi dalam situasi yang tenang tanpa ancaman.

- Mendorong penggunaan bahasa sebagai salah satu cara untuk mengorganisasikan ide.

- Menyusun pengalaman pembelajaran dalam seluruh bidang pembelajaran untuk mendorong penggunaan bahasa dalam menyelesaikan masalah, melaporkan, membandingkan dan mengevaluasi

- Menyusun pengalaman dimana anak bisa bekerja dalam tim sebanyak dua atau empat orang untuk mendorong penggunaan bahasa secara alamiah.

- Mengadakan umpan balik yang konstan dan interaksi verbal antara guru dan anak sebagai proses aktifitas belajar.

- Menyediakan kesempatan bagi anak untuk menyatakan sesuatu baik secara formal maupun informal.

Teknik stimulasi yang dikemukaan Yawkey (1981) tersebut akan dijadikan kerangka dasar dalam menganalisis apakah stimulasi yang dilakukan guru-guru TKN Pembina Kota Bandung sudah ideal atau belum.

\section{PROSEDUR PENELITIAN}

Penelitian ini menggunakan metode deskriptif dengan pendekatan kualitatif. Metode deskriptif digunakan untuk mengkaji bentuk aktivitas, karakteristik, perubahan, hubungan, kesamaan dan perbedaan dengan fenomena yang lain(Sugiyono,2007). Sesuai dengan karakter dari penelitian ini, semua keadaan, kondisi, aspek, atau variabel secara alami berjalan sesuai dengan kenyataan yang sebenarnya terjadi. Tidak terjadi perlakuan-perlakuan atau manipulasi tertentu terhadap variabel agar sesuatu terjadi pada variabel.

Adapun tempat penelitian adalah di tiga TK Pembina se-Kota Bandung, yaitu TK Pembina Sedang Serang, TK Pembina Negeri Centeh dan TK Pembina Citarip. TK pembina dipilih sebagai tempat penelitian karena diasumsikan sebagai TK ungguldan memiliki fungsinya sebagai pembina bagi TK lain. 
Subjek penelitian adalah guru TK Pembina se-Kota Bandung yang mengajar di kelas B. Kuesioner tertutup dan terbuka digunakan untuk mengetahui stimulasi yang digunakan guru dalam rangka mengembangkan kemampuan bahasa. Kuesionersebanyak 37 pertanyaantersebutberisiteknikstimulasi pada pembelajaran yang ideal dalam pembelajaran bahasabagianakmenurutYawkey (1981) dalambukuLanguageArts and the Young Child. Gurubolehmemilihlebihdarisatupilihansesuaidenganapa yang biasadialakukan di kelas. Setelahdidapatinformasidarikuesioner, kemudiandilakukanobservasi. Berikutadalahpenjabarannyalebihrinci. Selain itu, dilakukan juga observasi untuk tabulasi data.

\section{PEMBAHASAN}

\section{Hasil Penelitian}

Gurusebagaifasilitatorutamadalam sekolahdituntutmemilikikemampuanmengelolakelas pembelajaran di diharapkanmampumenciptakansuasanakelas kondusifuntukmemupukkepercayaandirianakdalammengekespresikanidenyalewatbahasa lisan. Berbagaistimulasi yang dilakukan guru-guru TKN Pembina Kota Bandung disajikan berikut ini.

\section{a. Pengembangankefasihan berbahasa}

Dalampengembangankefasihan berbagaiteknikstimulasi yang

berbahasa, menurutYawkey perludimilikigurudiantaranyaadalah: Memberikankebebasan pada anakuntukmemberiresponberdasarkanpengalamandiasendiri dan menggunakanbahasadiasendiri, dan Mendoronganakuntukberbicaradengananaklainbaiksendirimaupundalamkelompoksebagaima nadenganguru, sehinggalawanbicaraanakmayoritasadalah teman sebayanyadari pada guru.

Dari 14 guru yang dimintamengisikuesoner, 13 orangatau 95\% gurumengatakanmelakukansemuateknik dan metodauntuk mengembangkan kefasihanberbicaraanak. Sedangkansatugurumenyatakanhanyamemilihpoin a dan b saja dalammenstimulasikefasihanberbicaraanak. Untuklebihjelasnyadigambarkan pada diagramberikutini.

Iajarangmelakukanpoin

c.

\section{Diagram 1}

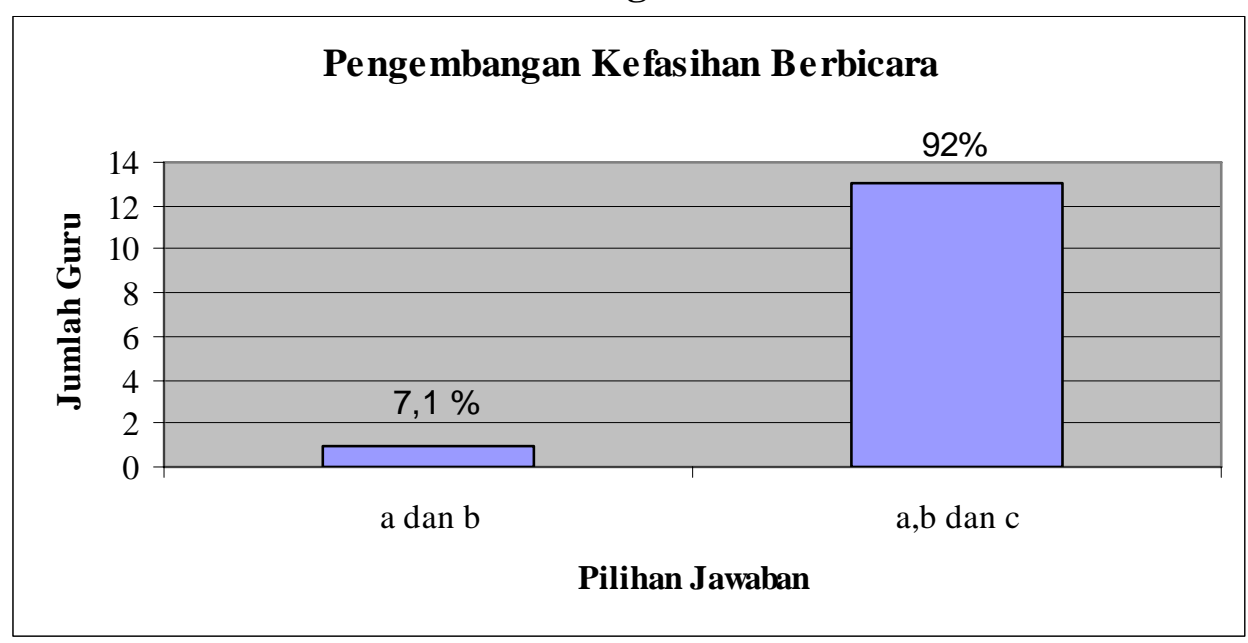

\section{b. Pengembangan Kemampuan Sintaksis}

Menurut Yawkey (1981), kemampuan sintaksis perlu diajarkan pada anak sejak dini, tapi tidak secara langsung. Teknik tersebut diantaranya dengan: (a) Menyusun permainan atau situasi dimana anak secara alamiah menggunakan fitur-fitur bahasa. (b) Menyediakan berbagai model fitur (guru, orang dewasa lain dan teman sebayanya, rekaman). (c) 
Mengevaluasi secara hati-hati kelanjutan perkembangan. (d) Mengevaluasi dialek anak yang berbeda dengan standar bahasa Indonesia, sehingga bahasa yang digunakan guru tidak jauh berbeda dengan bahasa yang digunakan anak.

Sebanyak 36\% guru dari 14 orang menjawab melakukan semua teknik menstimulasi kemampuan sintaksis tersebut. Sedangkan $29 \%$ hanya melakukan poin b, c dan d. Kemudian masing-masing 14\% melakukan poin a, c dan d serta a dan b. dan hanya $7 \%$ yang menjawab hanya melakukan poin a saja. Berikut adalah diagram yang menggambarkannya.

\section{Diagram 2}

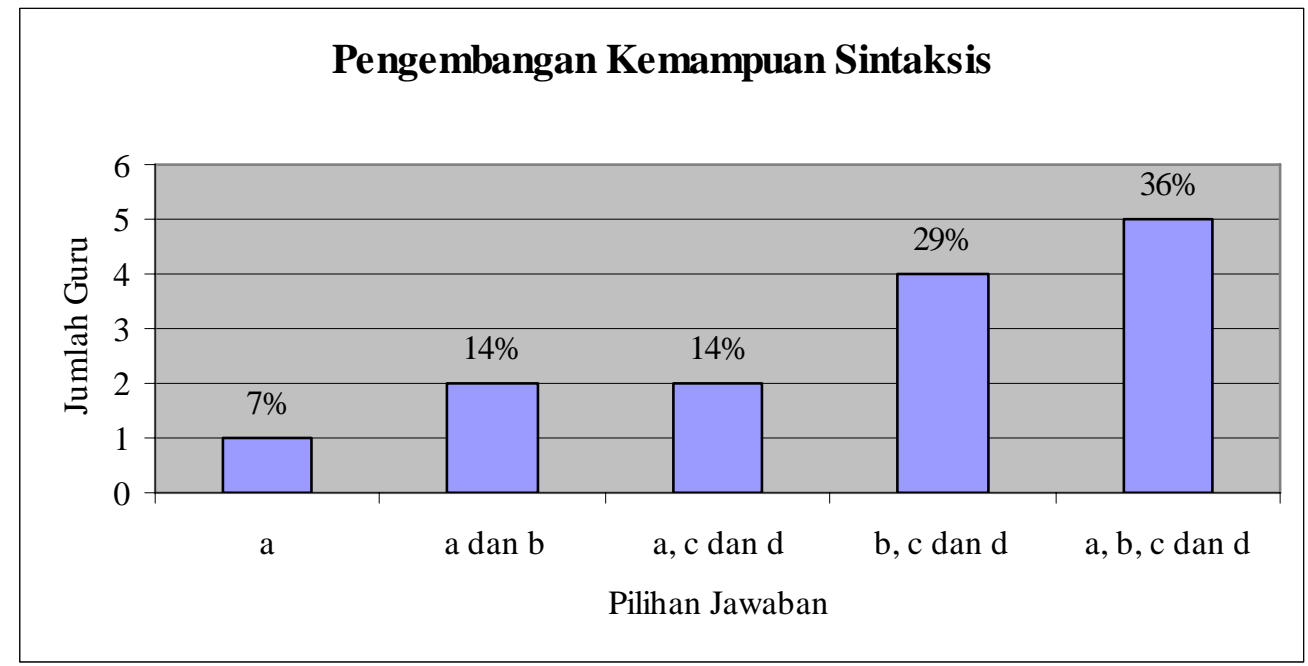

\section{c. Pengembangan Penguasaan Kosa Kata}

Penguasaan kosa kata merupakan hal yang sedang berkembang dengan pesat pada tahap perkembangan bahasa anak usia dini. Penguasaan kosa kata pada anak usia TK (4 - 5 tahun) idealnya sekitar 1250 s.d. 2150 kata. Untuk menstimulasi kemampuan tersebut, Yawkey menyatakan bahwa guru sebaiknya melakukan hal-hal beriku ini: (a) menyusun pengalaman pembelajaran di bidang sains, pengetahuan sosial, matematika, kesehatan dan keahlian kecakapan hidup yang memasukan pembelajaran kosa kata baru bagi anak, (b) memastikan kosa kata baru yang dipelajari tidak terlalu banyak sehingga mudah diasimilasikan oleh anak, (c) menyusun pengalaman pembelajaran lanjutan yang membuat anak menggunakan kosa kata baru secara alamiah dan membantu pengembangan konsep makna dari kata baru tersebut, dan terakhir (c) mengintegrasikan penggunaan bahasa dalam kehidupan sehari-hari baik di dalam maupun di luar sekolah.

Guru yang melakukan semua poin tersebut hanya sebanyak 51 \%. Sedangkan sisanya hanya melakukan beberapa poin dan 7\% tidak menjawab poin karena jarang melakukan hal tersebut. Berikut adalah gambaran penyebaran persentasi pilihan jawaban mengenai pengembangan penguasaan kosa kata.

\section{Diagram 3}




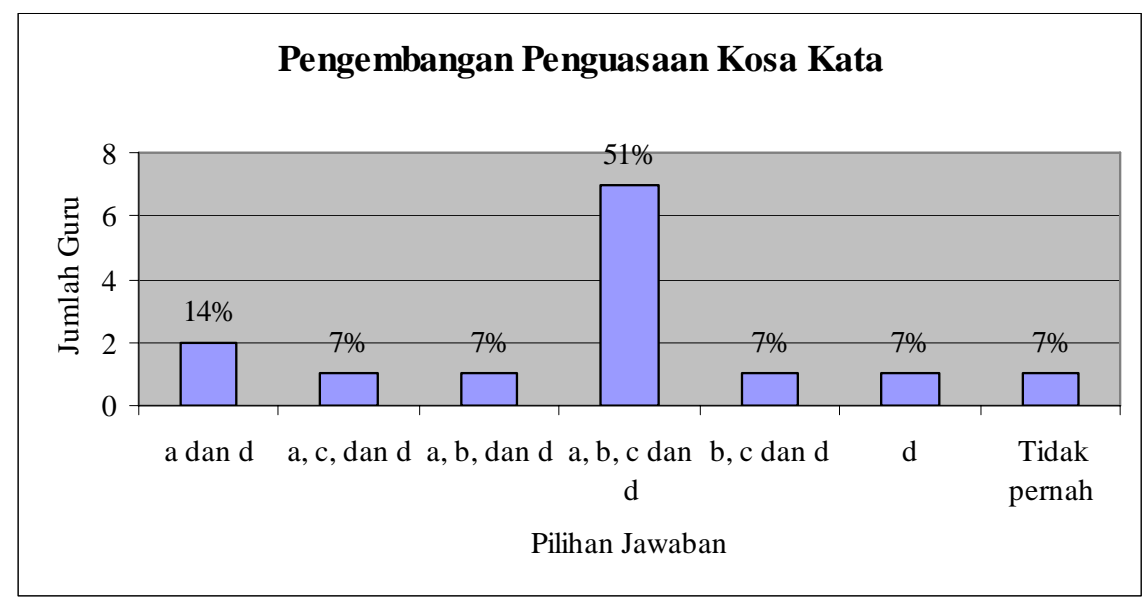

d. Pengembangan Pengintegrasian Kemampuan Bahasa dalam Kehidupan Sehari - hari

Yawkey (1981) mengemukakan bahwa apa yang dipelajari anak idelanya bisa diintegrasikan dalam kehidupan sehari-hari. Hal yang bisa dilakukan untuk mencapai tujuan tersebut adalah dengan: (a) menyusun pengalaman pembelajaran yang membuat anak mendeskripsikan kehidupan di luar sekolah (kegiatan, tempat, dan benda-benda yang berhubungan dengan kehidupan pribadi anak), (b) mendorong anak untuk berbagi dengan anak lain dan orang dewasa tentang reaksi dan perasaannya mengenai apa yang terjadi di sekolah dan diluar sekolah, serta (c) menyertakan anggota dan kegiatan masyarakat dalam pengalaman pembelajaran di kelas.

Dari ketiga hal tersebut diatas, sebanyak 79\% guru telah melaksanakan semuanya, sedangkan $7 \%$ atau satu orang guru, hanya mengerjakan poin b dan c. Jabarannya adalah sebagai berikut.

Diagram 4

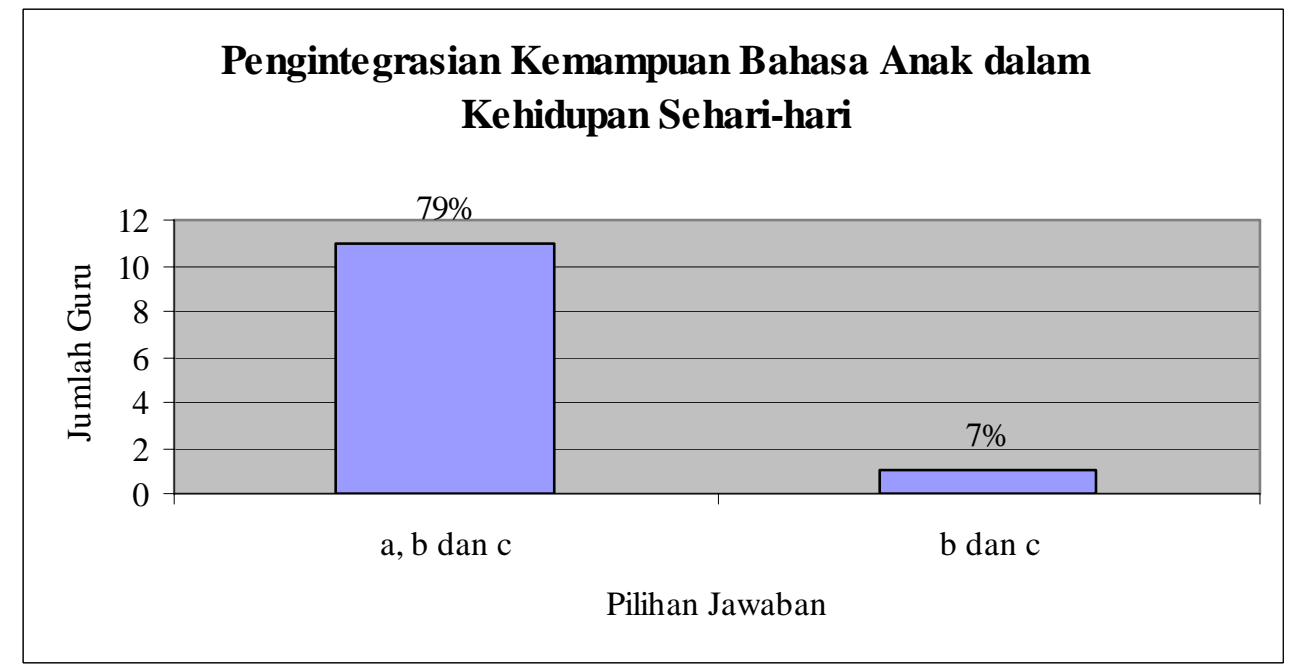

\section{e. Pengembangan Kemampuan Mengekspresikan Diri Sendiri}

Menurut Yawkey (1981), mengekpresikan ide merupakan kemampuan yang harus dikembangkan oleh guru pada anak. Diantara stimulasi yang bisa diberikan adalah: (a) menerima dan menghargai perasaan dan respon anak, (b) menyusun situasi yang mendorong respon kreatif dan penggunaan imajinasi, serta (c) menyediakan waktu dan tempat untuk anak berfikir dan berimajinasi dalam situasi yang tenang tanpa ancaman.

Lima puluh persen guru telah melakukan ketiga stimulasi diatas. Sisanya sebanyak masing - masing $21 \%$ hanya melakukan poin a dan a serta b. Sedangkan 7\% melakukan poin c saja. Diagram dibawah ini menggambarkan sebaran persentase tersebut.

\section{Diagram 5}




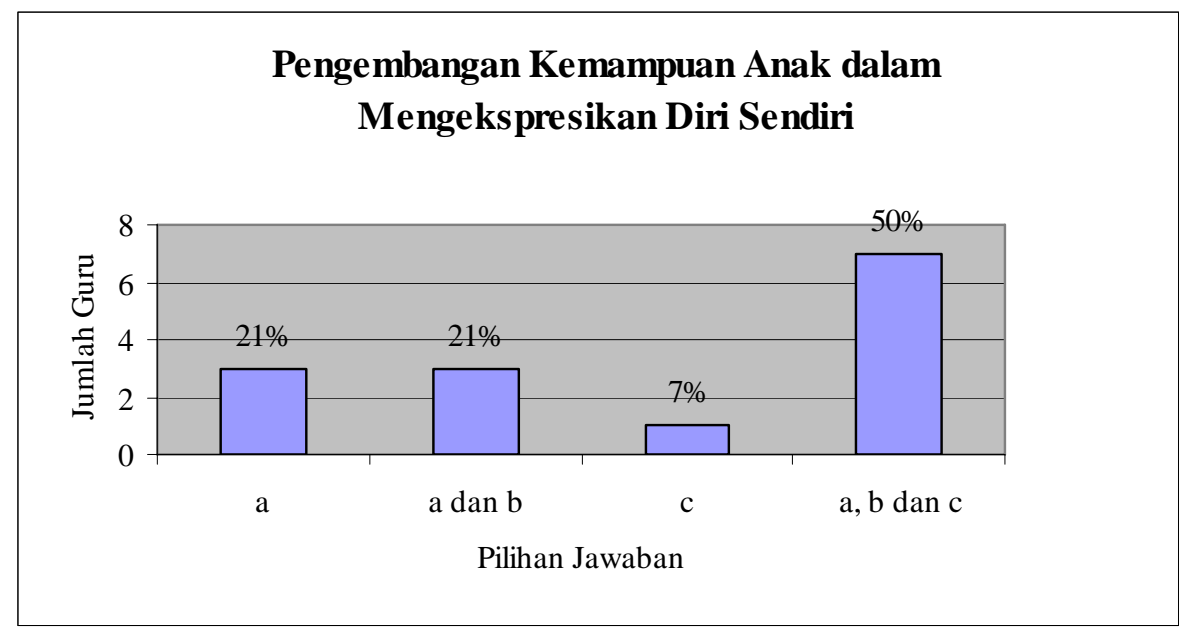

\section{f. Mendorong Penggunaan Bahasa Sebagai Salah Satu Cara Untuk Mengorganisasikan Ide.}

Seorang guru dituntut untuk menstimulasi kemampuan anak dalam menggunakan bahasa untuk mengorganisasikan ide. Yawkey dkk (1981) mengemukakan banyak hal yang bisa dilakukan untuk menstimulasi kemampuan tersebut, diantaranya: (a) menyusun pengalaman pembelajaran dalam seluruh bidang pembelajaran untuk mendorong penggunaan bahasa dalam menyelesaikan masalah, melaporkan, membandingkan dan mengevaluasi, (b) menyusun pengalaman dimana anak bisa bekerja dalam tim sebanyak dua atau empat orang untuk mendorong penggunaan bahasa secara alamiah, (c) mengadakan umpan balik yang konstan dan interaksi verbal antara guru dan anak sebagai proses aktifitas belajar, serta (c) menyediakan kesempatan bagi anak untuk menyatakan sesuatu baik secara formal maupun informal.

Hanya 56\% saja guru yang melakukan semua poin tersebut di atas. Sisanya menjawab dengan bervariasi. Yang menjawab a dan b serta c dan d masing-masing 14\%, yang menjawab hanya c serta b dan d sebesar masing-masing $7 \%$. Sedangkan sisanya, 7\% menjawab poin d saja. Berikut ini adalah gambaran diagramnya.

Diagram 6

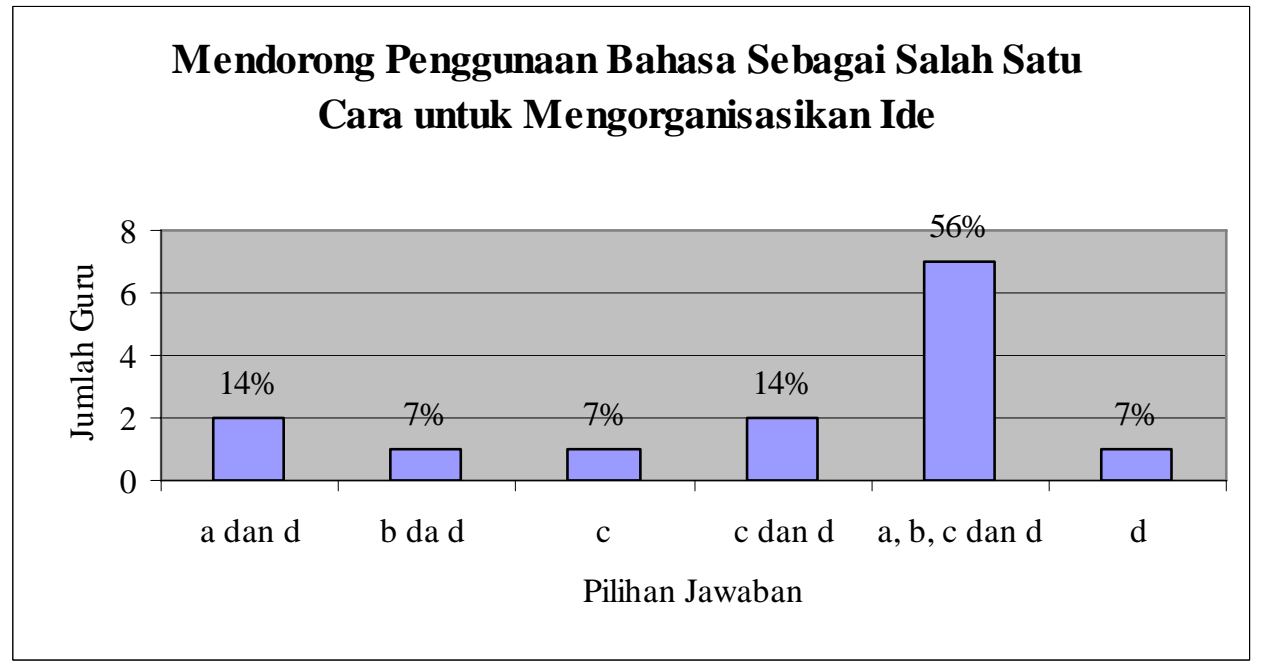

\section{Pembahasan}

Gurumerupakanfaktor yang sangatpentingdalampengembangankemampuan berbahasa anak. Secara global tugas gurusebagaiprofesimeliputimendidik, mengajar, dan melatih. Mendidikberartimeneruskan dan mengembangkan ilmupengetahuan dan teknologi. Sedangkanmelatihberarti mengembangkan keterampilan-keterampilan pada siswa. 
Dalamhalpengembangankemampuan berbahasa, lebihkhususlagi Logan (1972) menyatakanhalberikut:

Guru yang bertanggungjawabakanmenciptakanlingkunganbelajar yang mendukungkompetensi berbahasa dalamkomunikasi yang kreatif, karenakomunikasikreatifadalahdasarbagikesuksesandalamhidup.

Untukmenciptakanlingkunganbelajartersebut, Logan menambahkanbahwaselain gaya bicaraguru, polakepemimpinangurudalam pembelajaran pun sangatmempengaruhi pula. Menurut Logan, ada beberapa penelitian yang diantaranya telah dilakukan White dan Pitt yang menemukan bahwa kemampuan bahasa di kelas yang demokratis lebih tinggi dari pada di kelas yang otoriter. Di kelas yang demokratis, anak lebih berabi untuk mengeluarka pendapatnya sehingga kelas menjadi lebih efektif. Hasil penelitian tersebut pun senada dengan penelitian-penelitian lai yang dilakukan Flanders, Perkins, Polansky dan Whitehall (Logan:1972).

\section{SIMPULAN}

Berdasarkan hasil kajian yang telah dipaparkan, disimpulkan betapa penting kemampuan guru dalam menciptakan stimulasi-stimuliasi kebahasaan. Lebih rinci lagi, khusus untuk menstimulasi kemampuan berbicara, Yawkey (1981) meramu secara detail stimulasi apa saja yang bisa dilakukan untuk mengembangkan kemampuan bahasa ekpresif tersebut. Poin yang dipaparkan untuk menstiulasi kemampuan berbicara diantaranya tentang (1) pengembangan kefasihan berbahasa, (2) pengembangan kemampuan sintaksis, (3) pengembangan penguasaan kosa kata, (4) pengembangan pengintegrasian kemampuan bahasa dalam kehidupan sehari-hari, (5)pengembangan kemampuan mengekspresikan diri sendiri.

Dari lima poin pengembangan menurut Yawkey tersebut, dari hasil penelitian dengan menggunakan kuesioner, hampir 50\% guru ketiga TKN Pembina Kota Bandung telah melaksanakan semua kategori dari poin-poin diatas. Bahkan untuk pengembangan pengintegrasian kemampuan bahasa dalam kehidupan sehari-hari mencapai 79\% guru telah melaksanakannya. Sedangkan untuk pengembangan sintaksis hanya 39\% dan pengembangan penguasaan kosa kata 29\%. Guru-guru pun tidak mencantumkan stimulasi lain selain pilihan kategori yang sudah disediakan.

Diharapkan kemampuan guru-guru TKN Pembina Kota Bandung sudah sesuai dengan konsep stimulasi yang dikemukakan Yawkey dkk (1981) ini bisa disebarkan ke berbagai guru-guru lain melalui berbagai forum dan kegiatan. Sehingga kemampuan guru dalam menstimulasi kemampuan bahasa anak usia dini bisa meningkat dan pada gilirannya kemampuan bahasa anak usia dini bisa berkembang dengan baik.

\section{DAFTAR PUSTAKA}

Bredekamp, R.A.dkk (1992). What Does Research Say About Early Childhood Education ?. [on line], tersedia, http : // www.nerel.org / sdrs / areas / stw-esys / 5erly-ch.htm, [November, 2003].

Gautama (2002) UNJ Menggelar Seminar Pendidikan Anak Usia Dini [http//www.sriwijaya post on line]

Hoorn, Judith. dkk (1993). Play at the Center of the Curriculum. New York : Macmillan Pub. Comp.

Logan, Lilian M dkk (1972) Creative Communication, Teaching the Language Arts

Musfiroh, Tadkiroatun (2009) Menumbuhkembangkan Baca-Tulis Anak Usia Dini. Jakarta: Grasindo

Musthafa, B. (2002). Perkembangan Anak Usia Dini dan Implikasinya bagi Penulisan Bacaan Anak. Program Pasca Sarjana, Universitas Pendidikan Indonesia. Bandung. 
Santoso, Soegeng. (2002). Pendidikan Anak Usia Dini. Jakarta : Citra Pendidikan.

Semiawan, Conny. (2002). Belajar dan Pembelajaran dalam Taraf Usia Dini : pendidikan prasekolah dan sekolah dasar. Jakarta ; Prehallindo

Solehudin (2002) Pendidikan Anak Usia Dini. Bandung: Rosda Karya

Sugiyono (2007) Metode Penelitian Pendidikan, Bandung: Alfabeta

Supriadi, Dedi. (2002). "Isu-isu tentang Pendidikan Anak Usia Dini (Di Indonesia)". Makalah pada seminar Membangun Masa Depan Jawa Barat melalui Peningkatan Layanan Pendidikan Anak Usia Dini.Fakultas Ilmu Pendidikan. UP I Bandung.

Yawkey, Thomas D dkk (1981) Languange Arts and the Young Child. Illinois: Peackok Publisher

Yusuf LN, Syamsu. (2001), Psikologi Perkembangan Anak dan Remaja. Bandung: Remaja Rosdakarya. 